\title{
The Performance of The Female Employees in Public Service
}

\author{
${ }^{1}$ TITI DARMI, ${ }^{2}$ AGUSSALIM \\ ${ }^{1}$ Faculty of Social and Political Science, Muhammadiyah University of Bengkulu. Jl. Bali Kota Bengkulu,
${ }^{2}$ Faculty of Economic, Ekasakti University, Padang. Jl. Veteran Dalam No. 26, Padang, Sumatera Barat
email: ${ }^{1}$ titidarmi@umb.ac.id; ${ }^{2}$ agussikki@yahoo.com
}

Abstract. The purpose of this study is to find out the performance of female employees in public service at Class II Immigration Office Bukittinggi. The research method used is a mixed method research by combining the qualitative and quantitative data. The sources of data are primary and secondary data. Primary data is obtained through interviews, observations, and questionnaires to service users. The data from the distributed questionnaires are analyzed through frequency distribution table according to the respondents' statements. The number of respondents as the service users is 45 and 7 informants from the Class II Immigration Office of Bukittinggi. The research result shows that the performance of the female employees is very good with a contribution of $84.4 \%$ of the respondent's answer in assessing the employees' discipline in starting and completing the service, responsibility in completing the tasks given, and show good attitudes to the society. In performing their job, they apply roles, duties and responsibilities properly according to the main tasks and functions (tupoksi). Efforts and commitments from the stakeholders in improving the performance quality of the female employees are categorized well so that female employees can overcome any obstacles encountered.

Keywords: Performance, Female Employees, Public Service

\section{Introduction}

The role of women in the development process is generally very low, especially in the government sector (Darmi, 2016). In this reform era, the rapid national development in all fields requires reliable workforce (Agussalim, 2011) with a good performance that can contribute to the national development sustainability through the improvement of the existing human resources in a professional way.

Performance is identical to the quality of work reflected in one's attitude and behavior in performing the tasks that assigned to. Someone is having a high performance if he/she has technical and ethical standards according to the profession itself (Dobos, 2014). Human resources in an organization should have various characteristics including the ability/ professionalism of work, motivation, and performance (Ciobanu \& Androniceanu, 2015). In addition, employees' motivation and discipline contribute greatly to the organizational performance (Agussalim,
2016). These components are closely related and must be possessed by all employees who perform daily tasks, especially women. At a certain level of employment, (particularly in services area) women strongly support the good quality of work (Amin \& Islam, 2014).

In terms of quantity, women comprise slightly more than a half of the population in Indonesia. This greater amount should allow women to have equal access as men in all various areas of life such as social, cultural, economic, and political. However, this idealism has never been realized since the access to some of the areas is still limited for women (Yuli Hesti Wahyuningsih, et al., 2008).

The lack of women participation in many sectors of life cannot be separated from the socio-culture of Indonesian society in general (Darmi, 2016), concerning the role of tradition and transition. The role of tradition or domestic includes the role of women as wives, mothers, and household managers; while the transition role includes

Received: April 20, 2017, Revision: July 31, 2017, Accepted: December 15, 2017

Print ISSN: 0215-8175; Online ISSN: 2303-2499. DOI: http://dx.doi.org/10.29313/mimbar.v33i2.2384.291-300

Accredited B based on the decree No.040/P/2014, valid on February, 18, 2014 until February, 18, 2019. Indexed by DOAJ, Sinta, IPI 
the definition of women as labor, community and development members. The transition role of women is related to the influencing factors such as motivation, strong desire to actualize themselves, the existence of beliefs, and positive things that can lead to success and help to improve the economics of their family, as well as having their own financial autonomy. However, living two roles at once as a worker and a housewife is not easy. These two roles require women to be able to balance her home and work.

Furthermore, public service requires quality, or in a simple way quality service will provide an excellent service and meet customer expectations and needs (Darmi, 2016). Public service demands every element within the institution to empathize with the people it serves. Empathy implies the ability of the human resources, in this case, woman workers, to serve and be able to see things or problems from the community's point of view. It added with any profitable activity in a public organization which is not merely a physical product, but how to satisfy the community that has been served by the employees (Scupola \& Zanfei, 2016). Women employees are naturally more empathetic than men and more patience in providing services to the community so that they can provide a great quality of services (Seguino, 2000).

According to Parasuraman et al. (1988) cited by Fitzsimmons, James A. \& Fitzsimmons, Mona (2004) there are five indicators in public services, which are 1) Reliability, characterized by appropriate and correct service delivery; 2) Tangibility, characterized by adequate provision of human resources and other sources; 3 ) Responsiveness, characterized by the desire to serve consumers quickly; 4) Assurance, characterized by the level of awareness to the ethics and morals of service; and 5) Empathy, marked by the level of willingness to know the consumers' needs. These indicators became the author's guide to analyze the data and results of this study.

There are no previous studies examined the performance of female employees in the field of public services by using the five indicators above. This research is considered unique because the service cannot be touched and the communities can only perceive and rate the service given, thus it required responsive people to deliver the public service. Women are considered appropriate to deliver the public service because the nature of women is more compassionate and sensitive to the people's need.

Preliminary observation found a phenomenon about the performance quality of the female officers at class II Immigration office in Bukittinggi. The female employees seemed unfriendly by often forget to smile to the people, the long queue was still seen, lack of initiative to take actions outside the regulation and strong tendency to only wait for command from the leader, slow on service delivery, lack of motivation from the leader, and sometimes mood swinging resulting in the less good quality service from female bureaucrats officers.

Class II Immigration Office of Bukittinggi provides services to the community as a Technical Implementation Unit to directly facing and serving the people of Bukittinggi City. The Immigration Office in Bukittinggi has very important role of public service in the form of administration of making travel documents, visas and facilities, residence and status permit, intelligence, investigation and action, cross-border, and foreign cooperation as well as immigration information system.

The urgency of this research was to ensuring the implementation of the public services quality at Class II Immigration Office Bukittinggi which requires female employees' role assuming that female employees have more sensitivity and more painstaking in performing public service easily. Female Human Resources is one of the strategic aspects of Class II Immigration Office of Bukittinggi in serving its user community. The presence of women in the immigration service sector is an interesting phenomenon that requires more in-depth study. Thus, this study aims to find out the performance of female employees in providing services to the community at Class II Immigration Office in Bukittinggi.

\section{Research Method}

The method used was a mixed method of qualitative and quantitative. The populations were all Class II Immigration Officers in Bukittinggi and the service users served by the female officers. The informants were determined by using Purposive Sampling technique, which were (1) Head of Sub Division of Administration; (2) Head of General Affairs; (3) Head of Personnel Affairs; (4) Head of Sub-section Immigration Traffic; Counter Officer; and 2 officers who took a 
photo.

Sample (respondent) of the service users was determined using accidental sampling technique, with the sample chosen by chance or whoever those were being served by the female employees at the time of this research. Analysis of the descriptive data was based on the results of questionnaires distribution that had been analyzed through the frequency distribution table using frequency distribution statistics as follows: 1) Total cumulative of the largest weight value $=$ Number of respondents $\times$ weight of the largest measurement $=45 \times 5=225 ; 2$ ) Total cumulative of the smallest weight value $=$ Number of respondents $\times$ weight of the smallest measurement $=45 \times 1=45 ; 3$ ) The largest percentage value $=225 / 225 \times 100 \%$ $=100 \%$; 4) The smallest percentage value $=45 / 225 \times 100 \%=20 \%$; 5) Range value $=100 \%-20 \%=80 \% ; 6$ ) Interval value $=$ $80 \%: 5=16 \%$. Assessment criteria of each variable used is seen in Table 1.

Table 1

Assessment Criteria

\begin{tabular}{cc}
\hline $\begin{array}{c}\text { Percentage } \\
\text { Interval }\end{array}$ & Assessment Criteria \\
\hline $20-35$ & Very Less \\
$31-51$ & Less \\
$52-67$ & Medium \\
$68-83$ & Poor \\
$84-100$ & Very Poor \\
\hline
\end{tabular}

Source: Processed by the author

The most dominant indicator of the performance of the female employees was determined by summing up all the respondents' answers of each indicator and the highest percentage of each indicator was revealed as the most prominent or dominant indicator.

\section{Performance Concept of the Women Employees}

Employees' performance can be interpreted equal to the quality of work performed by the employees or can also be called professionalism where the work is undertaken as a principal activity to produce and possess a skill. Professionalism can be defined as a person's ability and skill in doing work according to his respective fields and levels.

In the context of female employees, their performance is largely determined by the level of their own ability reflected through daily behavior in the organization. Performance generated by women in the services field of public sector is the ability or talent in providing services as state apparatus customized with the knowledge field to carry out the tasks properly.

For women organization, their views or work motivations are strongly influenced by the public view on how women manage an organization so that women can play an active role (Rahminawati, et al., 2004). By providing comparative evidence in general, women workers remain to be reckoned, yet the effects of work similarity and income received vary greatly compared with men.

Many people presume that the low level of women's resources generally in the world, including in Indonesia, is caused by gender inequality, traditional socio-cultural system that have more alignments on men side, as well as the interpretation of religious teachings that are put men in a more profitable state and one step higher than women (Darmi, 2016); (Anastasiou et al., 2015).

Fortunately, the government has succeeded in realizing gender equity and equality in social and state life through several policies and programs. However, there are still many challenges and obstacles to apply the policies. Gender equity is more defined as the equality of conditions for men and women to gain opportunities as well as their rights as human to contribute and participate in all fields. Meanwhile, gender equality is a process and fair treatment both for women and men in state and community life, thus there is no standardization of gender roles, double burden, subordination, marginalization, and violence to women and men (BPS RI, 2015).

Women's struggle to work has become an achievement and now they begin slowly to have the same rights as men. At their respective levels in services, women have proven that they have achieved a highperformance level (Amin \& Islam: 2014); (Anastasiou et. al., 2015).

After all, the role of women as a workforce in the public sector cannot be ignored. The increasing demand for women workers has increased the number of women in the workplace (BPS RI: 2015). As income generators, data show the number of working women is increasing. In 2014, the Labor Force Participation Rate (TPAK) of women 
was about 50.22 percent which increased over the previous 10 years (49.23 percent). Consequently, the higher number of working women will increase the women's productivity role.

\section{The Concept of Public Service}

Basically, every human needs service, or it can be said that services cannot be separated from humans' life. People will always need services during their life. According to the life cycle theory of leadership (LCTL), physical service is demanded high in early humans' life (baby), but as people grow older, the dependency of the physical service will be decreased (Sinambela, 2006). Lijan states that public service is defined as providing service to a person or community with an interest to the organization in line with the established rules and procedures (Sinambela, 2006).

The Decree of Ministry of State for Administrative Reform in 2003 implies that one of the services provided by Class II Immigration Office of Bukittinggi is administrative service by issuing the documents. The service provider must provide good, easy, and cheaps services. In addition, excellent public services is one of the indicators of a good governance (Baharuddin, 2015).

To carry out the public services, human resources (women) are needed. Also, commitment and integrity of human resources have a significant influence in the organizational performance (Ariany \& Putera, 2013). Reflection of the service users' satisfaction greatly affects the quality of services provided by the service providers (Brady et al., 2002).

The performance quality of the women officers in the field of public services is seen from how the public rate the services delivered and reflected in the community's satisfaction. Thus, the quality of service affects the performance of the female employees at Class II Immigration OfficeBukittinggi. According to Parasuraman et al., (1988) determination in public service consists of five aspects: 1) Reliability; 2) Tangibility; 3) Responsiveness; 4) Assurance; 5) Empathy. The measurement of service quality by using these 5 indicators is known as service quality model (SERVQUAL). It was confirmed that if the female employees apply these five indicators properly, then the service users will get an excellent service.

\section{Descriptive Analysis of Personnel and Data Source}

Human Resources (HR) apparatus at Class II Immigration Office Bukittinggi by gender can be read in Table 2. The numbers of male apparatus are 24 people $(65 \%)$ and female are 13 people (35\%). This number is very influential in the working management which requires more physical power as seen from the table above. It tells that male employees are more dominant than female employees.

Table 2

Employees Characteristics by Gender

\begin{tabular}{cccc}
\hline No & Gender & Total & Percentage \\
\hline 1 & Male & 24 & $65 \%$ \\
2 & Female & 13 & $35 \%$ \\
& Total & 34 & $100 \%$ \\
\hline
\end{tabular}

Source: Personnel Data of Class II Immigration Office Bukittinggi Year 2016

Next, description about the education level of apparatus at Class II Immigration Office Bukittinggi can be seen in Table 3.

\section{Table 3 \\ Employees Characteristics by Education}

\begin{tabular}{cccc}
\hline No & Education Level & Total & $\begin{array}{c}\text { Percent- } \\
\text { age }\end{array}$ \\
\hline 1 & Post Graduate & 1 & $2,7 \%$ \\
2 & Undergraduate & 19 & $51,4 \%$ \\
3 & Diploma III & 6 & $16,2 \%$ \\
4 & $\begin{array}{c}\text { Junior High } \\
\text { School }\end{array}$ & 11 & $29,7 \%$ \\
& Total & 37 & $100 \%$ \\
\hline
\end{tabular}

Source: Personnel Data of Class II Immigration Office Bukittinggi Year 2016

The education levels of the employees show the potential to have a high level of professional knowledge and attitude to develop services to the community. The numbers of employees who have passed Undergraduate are 19 people, 1 person is having a Master degree, 6 people graduated from Diploma III, and the last 11 people are graduated from junior high school.

\section{Performance of the Female Employ- ees in Public Services at Class II Im- migration Office Bukittinggi}

Based on the questionnaire results, the respondents' answers on the performance of 
the female employees in the public service are as follows:

\section{Reliability}

The ability of female employees in providing services to the community has met the expectation such as the ability to keep promises, problem-solving skills, and to minimize the errors.

The indicators of Reliability of the female employees in serving the public consists of four statements which taken from respondents' answers and shown in table 4

Community responds to the question No. 1a about the service procedure given by the female employees to the community is Very Good stated by $55.6 \%$ of the respondents and the rest of $44.4 \%$ give a Good statement. For question No.1b on providing careful and reliable service to the community, $60 \%$ state Very Good and 40\% state Good. Then, the responses to the question No. 1c about providing an easy and uncomplicated service to the community shows that $48.9 \%$ state Very Good and the rest $51.1 \%$ state Good. So, it can be concluded that the easy and uncomplicated service provided by the female employees is categorized Good. For questions $1 \mathrm{~d}$ about the time spent by the female employees in delivering service is categorized
Good which is proved by $42.2 \%$ state Very Good and $57.8 \%$ state Good.

\section{Tangibility}

This indicator consists of four questions about things that are seen and perceived during the service delivery by the female employees in the public service, which the respondents' answers are shown in the following table.

For question No. 2a about the form of service provided, $31.1 \%$ state Very Good and $68.9 \%$ stated Good. It means the form of service provided by female employees to service users are categorized Good. For question $2 \mathrm{~b}$ about the clarity of the information given is rated Very Good by $53.3 \%$ and the remaining $46.7 \%$ say Good. It means this indicator is categorized Very Good. Question $2 c$ regarding courtesy and hospitality when serving the society with the result $11.1 \%$ of the respondent's statement state Very Good, $42.2 \%$ state Good, $355 \%$ choose Medium and the remaining $11,1 \%$ answer Poor. It can be interpreted that the politeness and hospitality of the female employees are categorized Good. Statements for question 2d about an equal treatment to every society served shows that $22.2 \%$ answer Very Good, $62.2 \%$ state Good, and the remaining $15.5 \%$ state Medium. In conclusion, of the four questions

Table 4

Reliability of the Female Employees

\begin{tabular}{|c|c|c|c|c|c|c|c|c|c|c|c|c|}
\hline \multirow{3}{*}{$\begin{array}{c}\text { No } \\
\text { Statement }\end{array}$} & \multicolumn{10}{|c|}{ Alternative Answer } & \multicolumn{2}{|c|}{ Total } \\
\hline & \multicolumn{2}{|c|}{ Very Good } & \multicolumn{2}{|c|}{ Good } & \multicolumn{2}{|c|}{ Medium } & \multicolumn{2}{|c|}{ Poor } & \multicolumn{2}{|c|}{ Very Poor } & \multirow[b]{2}{*}{$\mathrm{F}$} & \multirow[b]{2}{*}{$\%$} \\
\hline & $\mathrm{F}$ & $\%$ & $\mathrm{~F}$ & $\%$ & $\mathrm{~F}$ & $\%$ & $\mathrm{~F}$ & $\%$ & $\mathrm{~F}$ & $\%$ & & \\
\hline $1 a$ & 25 & 56 & 20 & 40 & 0 & 0 & 0 & 0 & 0 & 0 & 45 & 100 \\
\hline $1 b$ & 27 & 60 & 18 & 44 & 0 & 0 & 0 & 0 & 0 & 0 & 45 & 100 \\
\hline $1 \mathrm{c}$ & 22 & 49 & 23 & 51 & 0 & 0 & 0 & 0 & 0 & 0 & 45 & 100 \\
\hline $1 d$ & 19 & 42 & 26 & 58 & 0 & 0 & 0 & 0 & 0 & 0 & 45 & 100 \\
\hline Average & \multicolumn{2}{|c|}{$51.70 \%$} & \multicolumn{2}{|c|}{$48.30 \%$} & \multicolumn{2}{|c|}{$0 \%$} & \multicolumn{2}{|c|}{$0 \%$} & \multicolumn{2}{|c|}{$0 \%$} & \multicolumn{2}{|c|}{$100 \%$} \\
\hline
\end{tabular}

Source: Research result, Processed: 2016

Table 5

Tangibility of the Female Employees

\begin{tabular}{|c|c|c|c|c|c|c|c|c|c|c|c|c|}
\hline \multirow{2}{*}{$\begin{array}{c}\text { No } \\
\text { Statement }\end{array}$} & \multicolumn{10}{|c|}{ Alternative Answer } & \multicolumn{2}{|c|}{ Total } \\
\hline & $\mathrm{F}$ & $\%$ & $\mathrm{~F}$ & $\%$ & $\mathrm{~F}$ & $\%$ & $\mathrm{~F}$ & $\%$ & $\mathrm{~F}$ & $\%$ & $\mathrm{~F}$ & $\%$ \\
\hline $2 a$ & 14 & 31 & 31 & 69 & 0 & 0 & 0 & 0 & 0 & 0 & 45 & 100 \\
\hline $2 b$ & 24 & 53 & 21 & 47 & 0 & 0 & 0 & 0 & 0 & 0 & 45 & 100 \\
\hline $2 c$ & 5 & 11 & 19 & 42 & 16 & 36.56 & 5 & 11.1 & 0 & 0 & 45 & 100 \\
\hline $2 d$ & 10 & 22 & 22 & 62 & 7 & 15.56 & 0 & 0 & 0 & 0 & 45 & 100 \\
\hline Average & \multicolumn{2}{|c|}{$29.40 \%$} & \multicolumn{2}{|c|}{$55 \%$} & \multicolumn{2}{|c|}{$12.80 \%$} & \multicolumn{2}{|c|}{$2.80 \%$} & \multicolumn{2}{|c|}{$0 \%$} & \multicolumn{2}{|c|}{$100 \%$} \\
\hline
\end{tabular}

Source: Research result, Processed: 2016 
about the things seen during the services provided by the female officers is considered Good.

\section{Responsiveness}

Responsiveness is a willingness to listen and respond to the customers' complaints in an effort to satisfy them, for example, being able to provide information correctly and appropriately, does not show a busy body attitude, and be able to provide immediate help. In the indicator of Responsiveness, there are four questions related to the service given by the female employees which generated respondents' answers as seen in table 6:

Question No. 3a about the willingness of the female officers to respond the community's complaints as quickly as possible resulted in $31.1 \%$ of the respondent rate Very Good and the remaining $68.9 \%$ give a Good answer, which means their responsiveness is categorized Good. For question 3b in term of satisfying the needs of the community, the respondents answer Very Good by $24.4 \%$ and the remaining $75.6 \%$ answer Good. Furthermore, for question $3 c$ about giving the correct and appropriate information to the public, $46.7 \%$ choose Very Good option and the remaining $53.3 \%$ say Good. In other words, the female employees are categorized Good in giving the exact and correct information to the community. $48.9 \%$ answer Very Good the question 3d about the agile skill of female employees in providing services, and the remaining $51.1 \%$ state Good. In conclusion, the responsiveness of the women officers in serving the community is said to be Good.

\section{Assurance}

Assurance is the ability of the female employees to generate trust and confidence of the customers through knowledge, courtesy and appreciate customers' feelings, skills in providing information, and the ability to provide security in utilizing the services offered. Indicator of assurance or guarantee consists of four questions, which the respondents' answers can be seen in table 7 below.

For question No $4 a, 57.8 \%$ answer Very Good related to the public trust on the service given, and $42.2 \%$ state Good. Thus, the public trust to the services provided is categorized Very Good. The ability to provide a secure public service in question No. 4b is confirmed Very Good by the answers of $64.4 \%$, and the other $35.6 \%$ state Good. It means that the community trusts the women officers give an excellent service in providing security. $24.4 \%$ of the respondent answer Very Good for question No. 4c about the

Tabel 6

Responsiveness of the Female Employees

\begin{tabular}{|c|c|c|c|c|c|c|c|c|c|c|c|c|}
\hline \multirow{3}{*}{$\begin{array}{c}\text { No } \\
\text { Statement }\end{array}$} & \multicolumn{10}{|c|}{ Alternative Answer } & \multirow{2}{*}{\multicolumn{2}{|c|}{ Total }} \\
\hline & \multicolumn{2}{|c|}{ Very Good } & \multicolumn{2}{|c|}{ Good } & \multicolumn{2}{|c|}{ Medium } & \multicolumn{2}{|c|}{ Poor } & \multicolumn{2}{|c|}{ Very Poor } & & \\
\hline & $\mathrm{F}$ & $\%$ & $\mathrm{~F}$ & $\%$ & $\mathrm{~F}$ & $\%$ & $\mathrm{~F}$ & $\%$ & $\mathrm{~F}$ & $\%$ & $\mathrm{~F}$ & $\%$ \\
\hline $3 a$ & 14 & 31,1 & 31 & 69 & 0 & 0 & 0 & 0 & 0 & 0 & 45 & 100 \\
\hline $3 b$ & 11 & 24,4 & 34 & 75.6 & 0 & 0 & 0 & 0 & 0 & 0 & 45 & 100 \\
\hline $3 c$ & 21 & 46.7 & 24 & 53.3 & 0 & 0 & 0 & 0 & 0 & 0 & 45 & 100 \\
\hline $3 d$ & 22 & 48.9 & 23 & 51.1 & 0 & 0 & 0 & 0 & 0 & 0 & 45 & 100 \\
\hline Average & \multicolumn{2}{|c|}{$37.75 \%$} & \multicolumn{2}{|c|}{$62.25 \%$} & \multicolumn{2}{|c|}{$0 \%$} & \multicolumn{2}{|c|}{$0 \%$} & \multicolumn{2}{|c|}{$0 \%$} & \multicolumn{2}{|c|}{$100 \%$} \\
\hline
\end{tabular}

Source: Research result, Processed: 2016

Table 7

Assurance Provided by the Female Employees

\begin{tabular}{|c|c|c|c|c|c|c|c|c|c|c|c|c|}
\hline \multirow{3}{*}{$\begin{array}{c}\text { No } \\
\text { Statement }\end{array}$} & \multicolumn{10}{|c|}{ Alternative Answer } & \multicolumn{2}{|c|}{ Total } \\
\hline & \multicolumn{2}{|c|}{ Very Good } & \multicolumn{2}{|c|}{ Good } & \multicolumn{2}{|c|}{ Medium } & \multicolumn{2}{|c|}{ Poor } & \multicolumn{2}{|c|}{ Very Poor } & \multirow[b]{2}{*}{$\mathrm{F}$} & \multirow[b]{2}{*}{$\%$} \\
\hline & $\mathrm{F}$ & $\%$ & $\mathrm{~F}$ & $\%$ & $\mathrm{~F}$ & $\%$ & $\mathrm{~F}$ & $\%$ & $\mathrm{~F}$ & $\%$ & & \\
\hline $4 a$ & 26 & 57.8 & 19 & 42.2 & 0 & 0 & $\overline{0}$ & 0 & 0 & 0 & 45 & 100 \\
\hline $4 b$ & 29 & 64.4 & 16 & 35.6 & 0 & 0 & 0 & 0 & 0 & 0 & 45 & 100 \\
\hline $4 c$ & 11 & 24.4 & 21 & 46.7 & 13 & 28.9 & 0 & 0 & 0 & 0 & 45 & 100 \\
\hline $4 d$ & 3 & 6.67 & 25 & 55.6 & 14 & 31.1 & 3 & 6.67 & 0 & 0 & 45 & 100 \\
\hline Average & \multicolumn{2}{|c|}{$38.30 \%$} & \multicolumn{2}{|c|}{$45 \%$} & \multicolumn{2}{|c|}{$15 \%$} & \multicolumn{2}{|c|}{$1.70 \%$} & \multicolumn{2}{|c|}{$0 \%$} & \multicolumn{2}{|c|}{$100 \%$} \\
\hline
\end{tabular}

Source: Research result, Processed: 2016 
female employees show good personality to the public, $46.7 \%$ state Good and $28.9 \%$ state Medium. Respondents' answers indicate that the female employees have good personality. Question No. 4d related to the pleasant service that $6.67 \%$ state Very Good, $55.6 \%$ state Good, $31.1 \%$ state Medium and $6.67 \%$ state Poor. That means, the female employees have provided a pleasant service to the community. In conclusion, the assurance indicators above including public trust, security, good personal, and pleasant service of the female employees can be categorized well.

\section{Empathy}

Empathy is the ability or willingness to give personal attention, such as being friendly, understand the needs, and care for the customers. Empathy is needed for the continuity of service to the community in relation to the passport service. It also involves individual attention given to society, such as easy service, the ability to communicate, and understand the community needs.

Indicator of Empathy can be seen from the four questions and the respondents' answers as seen in table 8.

Question 5a state the willingness to give attention to the public, $4.44 \%$ of the answers are Very Good, $75.6 \%$ state Good and the remaining $20 \%$ state Medium. It can be concluded that the female officers have given personal attention that is categorized Good. Question 5b, $6.67 \%$ stated that the female officers are Very Good at respecting the peoples' feelings, $80 \%$ state Good, $13.3 \%$ state Medium. From the diversity of the answers it can be confirmed that the female employees have been Good in understanding the feelings of the community. $40 \%$ of the respondents' answers on question $5 \mathrm{c}$ related to the ability to understand the needs of the community shows Very Good, $57.7 \%$ state Good and 2.2\% state Medium. Therefore, the ability of female employees to understand the needs of society is Good. Question $5 d$ on the ability of the female employees to handle complaints from the com munity gain $20 \%$ Very Good answer, $77.8 \%$ state Good and the remaining $2.2 \%$ state Medium. Thus, the ability of women officers to handle obstacles from the community can be said Good. It means, the Empathy or concern of the female employ in delivering service can be said Good.

The performance of female employees in public service can be find out by comparing the total score of assessment answers of the 20 items by 3.820 with the highest total score $5 \times 45 \times 20=4.500$. The comparison result is 3.820: $4.500=0.848$ or $0.848 \times 100 \%=$ $84.8 \%$. Then, the value of $84.8 \%$ is in the percentage range interval of $84-100$. This result shows that the performance of women in public service class II of Immigration office Bukittinggi is Very Good.

The performance of female employees in the field of public service seen from these five indicators: (1) Reliability; (2) Tangibles; (3) Responsiveness; (4) Assurance; and (5) Empathy (Parasuraman. A, Zeithaml,V.A.: 1988) was Very Good confirmed by these five indicators or elements of public service which have applied properly in accordance with the expectations of service users, without a gap between the perception and expectation of the service users. In addition, an interview with male employees revealed that the performance of female employees was Very Good seen from their daily attitude and behavior in the organization. They were discipline in starting and completing the services, always responsible to accomplish the tasks given and being friendly in providing services to the community. In the workplace, women understand and perform their roles, duties and responsibilities well in the field of immigration.

The prominent or dominant indicator of the female employees' performance was determined by summing up the total score of each indicator.

\section{Table 8
Empathy of the Female Employees}

\begin{tabular}{|c|c|c|c|c|c|c|c|c|c|c|c|c|}
\hline \multirow{3}{*}{$\begin{array}{c}\text { No } \\
\text { Statement }\end{array}$} & \multicolumn{10}{|c|}{ Alternative Answer } & \multirow{2}{*}{\multicolumn{2}{|c|}{ Total }} \\
\hline & \multicolumn{2}{|c|}{ Very Good } & \multicolumn{2}{|c|}{ Good } & \multicolumn{2}{|c|}{ Medium } & \multicolumn{2}{|c|}{ Poor } & \multicolumn{2}{|c|}{ Very Poor } & & \\
\hline & $\mathrm{F}$ & $\%$ & $\mathrm{~F}$ & $\%$ & $\mathrm{~F}$ & $\%$ & $\mathrm{~F}$ & $\%$ & $\mathrm{~F}$ & $\%$ & $\mathrm{~F}$ & $\%$ \\
\hline $5 a$ & 2 & 4.44 & 34 & 75.55 & 9 & 20 & 0 & 0 & 0 & 0 & 45 & 100 \\
\hline $5 b$ & 3 & 6.68 & 36 & 80 & 6 & 13.33 & 0 & 0 & 0 & 0 & 45 & 100 \\
\hline $5 c$ & 18 & 40 & 26 & 57.77 & 1 & 2.22 & 0 & 0 & 0 & 0 & 45 & 100 \\
\hline $5 d$ & 9 & 20 & 35 & 77.77 & 1 & 2.22 & 0 & 0 & 0 & 0 & 45 & 100 \\
\hline Average & \multicolumn{2}{|c|}{$17.79 \%$} & \multicolumn{2}{|c|}{$72.77 \%$} & \multicolumn{2}{|c|}{$9.44 \%$} & \multicolumn{2}{|c|}{$0 \%$} & \multicolumn{2}{|c|}{$0 \%$} & \multicolumn{2}{|c|}{$100 \%$} \\
\hline
\end{tabular}

Source: Research result, Processed: 2016 
Table 9

Percentage Distribution of the Female Performance Assessment in Public Service based on Research Indicators

\begin{tabular}{cccc}
\hline No. & $\begin{array}{c}\text { Research } \\
\text { Indicator }\end{array}$ & $\Sigma$ & $\%$ \\
\hline 1. & Reliability & 813 & 21,28 \\
2. & Tangibility & 737 & 19,29 \\
3. & Responsibility & 788 & 20,63 \\
4. & Anssurance & 747 & 19,56 \\
5. & Empaty & 735 & 19,24 \\
& TOTAL & $\mathbf{3 8 2 0}$ & $\mathbf{1 0 0}$ \\
\hline
\end{tabular}

Source: Attachment 3 and processed by the author

The table describes that the most dominant indicator is Reliability because it has the biggest contribution by $21.28 \%$ due to the female employees have fulfilled the community expectation in term of the ability to keep promises, solve problems immediately and the ability to minimize the errors.

\section{Obstacles Faced by Female Employ- ees}

\section{Impatient applicant to be served im- mediately}

In fact, some of the service users claimed that they were not satisfied with the service given despite the maximum effort have been provided. However, a balance between service users and service providers should be created in order to produce highquality services. Some obstacles faced by the female employees were the indiscipline of the service users, where they were not patience to wait and often came to the employee's desk and asked for their turn. Whereas, the female officers were required to check the completeness of documents carefully in order to avoid mistakes, especially on the registration of passport applicants. Service users demanded to open the services at the break time. These demands should be seen as a concern and innovation is sought to solve those complaints.

\section{Lack of public understanding about the existing Standards Operational Procedures (SOP)}

In conducting immigration services, both officers and users must comply with the procedures/ SOPs that have been determined. Based on the research results, many service users did not understand the service procedures and the female employees had to explain repeatedly. The officers were always required to be friendly, polite and kept smiling to the impatience service users who visited the desk officers at any time they want.
It is important to deliver massive information about Standards Operational Procedures (SOP) to the service users.

\section{Difficulties in dividing time between family and work}

The results showed there were problems from external factors outside the work environment. Multiple roles of the female employees affected their performance at work. Based on the interview with the female employees, they were difficult to divide time between work and family which both are important. The problem at home sometimes influenced the work. However, there is no significant improvement of performance of female employees if they can balance their roles.

\section{Factors of stress and fatigue}

The results showed some of the female employees were exhausted in carrying out their duties. Lack of officers created imbalances both time and physical, considering the number of officers were not comparable with the number of people who had matters regarding immigration, coupled with an accumulated load and also the dual role with the time division problem between families and work. These problems made the officers sometimes stressful and tired. Finally, the female officers must accomplish the work in a hurry and deadline followed by the moods that changed every day.

\section{Efforts to Address Problems}

\section{Implement services based on a new queue system}

Through the Directorate General of Immigration, Class II Immigration Office Bukittinggi changed the passport application queue with a new system, Head of Class II Immigration Office of Bukittinggi, Teguh Cahyono, B.A said that this new system is referring to the Circular Letter of the Director General of Immigration Number: IMIGR.01.01-0047 year 2016 on the Passport Service Queer Republic of Indonesia with a time limit system starting from 07.30 am until $12.00 \mathrm{pm}$. He explained that, this breakthrough is useful in realizing the service of publishing passport that meets the principle of certainty, speed, and ease. This system is much better than the previous one which based on quota resulted in many people were not well served.

\section{Provide Explanations and Under- standing}

Providing explanation and understanding 
about the immigration service procedure to the Security Officer in order to facilitate the public with the information about the service procedure might ease the tasks of the service officers. Thus, the service officers can run their job effectively and efficiently according to the service target. In addition, providing information through installation of banners and pamphlets installed in strategic areas was very useful for the community.

\section{Give Reward}

Giving reward is one of the ways to motivate the female employees in carrying out their duties. However, it should be given based on careful consideration, have default standards, and performed systematically or well programmed.

\section{Increase Human Relations}

The form of relationship as exemplified by Mr. Rahman Antoni Aziz's leader was establishing a harmonious relationship with the female employees, such as telling jokes or humors to reduce the stress level of the workload and planning for recreation with all employees at a certain time. He said ".... This recreation aims to create a balance between work and rest, but it can develop good relationships between superiors and subordinates as well as relationships among employees, it also helpful for health and employees' satisfaction."

\section{Motivate the Employees}

Similarly, Mrs. Ernawati realized her duty and role as a leader and a woman (Mother). Accordingly, she used her motherly instinct to motivate her employees by knowing their wishes, encouraging them to improve their spirit by helping them to achieve their ambitions and goals, making them feel important and necessary, listening to their complaints, discussing the results achieved and their disappointments, praising them, trying to understand, and maintaining their image.

\section{Conduct Training}

The result of interview with Mrs. Widia Nazinda about the efforts given in handling the obstacles faced by woman professionalism in public service, she said: "... All of the employees had been trained before placed in a job position, they were tested first by the Human Resource division and if passed they can stay in that position and will be guided by their senior". To improve the quality of the female employees either skill, knowledge, skill or mental courage, they are required to attend various trainings and educations.

\section{Participate in Education and Training (Dikpim)}

Education for immigration officers (Dikpim) is a special education conducted to develop human resources with knowledge, skills, and attitudes in performing immigration duties and functions that provide opportunity for the female employees to get technical education in the field of immigration for one year. Some efforts in overcoming the obstacles above are in line with the research conducted by Ariany, et al. (2013) that in improving the performance of the public service sector needs to improve human resources and qualified personnel that can contribute to the services provided.

\section{Conclusions}

Related to the performance of the female employees at Class II Immigration Office in Bukittinggi, conclusions are derived as follows: 1) the quality of women's performance in serving the community is very good. They have shown their ability and talent in providing services which are reflected in their behavior and attitude. Their professional commitment to work on time and follow the work cycle reflected in their daily lives' behavior in the organization; 2) the performance of women officers in the immigration service is categorized very well (Good) stated by $84.4 \%$ of the respondents. By relying on expertise, skills, and knowledge lead the officers to be discipline in starting and completing the service, responsible to the tasks given and be friendly to the service users. Also, the female employees understand and perform their roles, duties and responsibilities properly.

The dominant indicator of the quality of women's performance in public service is Reliability with the largest contribution of $21.28 \%$. The research results indicate that the five dimensions of the public service quality according to Parasuraman. A, Zeithaml. VA (1988) are still feasible and appropriate to be applied in the field of public services in order to maintain the service quality. Consequently, the services provided can meet the expectations of the service users (excellent service).

In carrying out the public service, female employees faced some obstacles, namely: 1) There are some impatient people 
who insist to be served promptly which has implications to the public perception about the service quality; 2) lack of understanding of the community about the procedure to be followed; 3) the female employees cannot balance their role as a housewife and an employee. Therefore, in order to improve their performance quality, some efforts must be made such as: (1) implement services based on the new queue system; (2) provide explanation and understanding to socialize the procedures to the community; (3) reward giving to a high performing employee; (4) establish good relationships between leaders and staff; (5) improve the capacity of employees through training, education, workshop etc.

\section{References}

Agussalim, M., Putri, A.R.M., \&Ali, H.(2016). Analysis Work Discipline And Work Spirit Toward Performance Of ( Case Study Tax Office Pratama Two Padang ). IJER, 13(6), pp.2541-2556.

Agussalim, M., Putri, A.R.M., \& Ali, H.(2011). Dasar-Dasar Manajemen Sumber Daya Manusia 1st ed. Ekasakti Press, ed., Padang, Sumatera Barat.

Amin, M. \& Islam, A.(2014). Are there more female managers in the retail sector? Evidence from survey data in developing countries. Journal of Applied Economics, 17(2), pp.213-228.

Anastasiou, S., Filippidis, K. \& Stergiou, K.(2015). Economic Recession, Austerity and Gender Inequality at Work. Evidence from Greece and Other Balkan Countries. Procedia Economics and Finance, 24(July), pp.41-49. Available at: http://www. sciencedirect.com/science/article/pii/ S2212567115006103.

Ariany, R.I.A. \& Putera, R.E. (2013). Analisis Kinerja Organisasi Pemerintah dalam Memberikan Pelayanan Publik di Kota Pariaman. Mimbar Unisba, 29(1), pp.3340.

Badan Pusat Statistik (BPS) RI.(2015). Indeks Pembangunan Gender 2014.

Baharuddin. (2015). Akuntabilitas Pelayanan Publik : Studi Kasus pada Pelayanan Perizinan Mendirikan Bangunan di Kota Makasar. Mimbar Unisba, 31 (2). pp. 263-270.

Brady, M.K., Cronin, J.J. \& Brand, R.R. (2002). Performance-only measurement of service quality : a replication and extension. , 55, pp.17-31.
Ciobanu, A. \& Androniceanu, A. (2015). Civil Servants Motivation and Work Performance in Romanian Public Institutions. Procedia Economics and Finance, 30(15), pp.164-174. Available at: http://www. sciencedirect.com/science/article/pii/ S2212567115012800.

Darmi, T., (a).(2016). Penerapan Prinsip Good Governance dalam Pelayanan Publik. Jurnal Administrasi Pembangunan FISIP UNRI, Vol 2 no 4.

Darmi, T., (b). (2016). Optimalisasi Peran Perempuan Berbasis Modal Sosial pada Sektor Pemerintahan Desa(Study pada Pengelolaan Dana Desa). Jurnal Antropologi: Isu-Isu Sosial Budaya, 18 (1) (Isu Sosial Budaya), pp.21-27. Available at: jurnalantropologi.fisip.unand.ac.id/ index.php/jantro/article/view/48.

Dobos, A. (2014). Experiential Learning for Professional Development in the Civil Service. Procedia - Social and Behavioral SciencesDobos, Á. (2014). Experiential Learning for Professional Development in the Civil Service. Procedia - Social and Behavioral Sciences, 116, 5085-5090. https://doi.org/10.1016/j. sbspro.2014.01.1078, 116, pp.50855090. Available at: http://www. sciencedirect.com/science/article/pii/ S1877042814010957.

Fitzsimmons, James A. \& Fitzsimmons, Mona. (2004). Service Management: Operation, Strategy, Information Technology. 4th ed., New York State: McGraw-Hill Companies.

Parasuraman.A, Zeithaml.V.A, and Berry. (1988). SERVQUAL: A Multiple-Item Scale for Measuring Consumer Perceptions of Service Quality. Journal of Retailing, vol 64 Number 1, pp.12-40.

Rahminawati, N., Hendarsyah, N.AR.,\& Umar, M. (2006). Kemampuan Manajerial Pengurus Organisasi Dalam Upaya Meningkatkan Kinerja Organisasi Islam Perempuan Di Jawa Barat. Mimbar Unisba, pp.143-164.

Scupola, A. \& Zanfei, A.(2016). Governance and innovation in public sector services: The case of the digital library.

Seguino, S.(2000). Gender Inequality and Economic Growth: A Cross - Country Analysis. World Development, 28(7), pp.1211-1230.

Sinambela, L. P.(2006). Reformasi Pelayanan Publik, Jakarta: Bumi Aksara.

Wahyuningsih, Y.H, \& Tafrikhuddin. (2008). Peran Perempuan Pada Sektor Jasa Pelayanan Perpustakaan Di Perpustakaan Universitas Gadjah Mada Yogyakarta. IImu Perpustakaan dan Informasi, IV no I. Available at: portalgaruda.org/article. php? 